\title{
Guidelines for target costing adoption in the development of products for the residential real estate market
}

\author{
Diretrizes para adoção do custeio-meta no processo de \\ desenvolvimento de produtos para o mercado imobiliário \\ residencial
}

\section{Reymard Savio Sampaio de Melo Ariovaldo Denis Granja}

\begin{abstract}
$\mathbf{T}$

his study focuses on the problems associated with the traditional practice of reducing costs in construction and the need to increase business competitiveness in the residential real estate sector. In this context, target costing is a promising approach to improve the competitiveness of companies by ensuring that the products launched on the market do not jeopardize the company's results and value delivery to customers. However, far too little attention is paid to target costing implementation by companies that develop residential real state products for sale and face strong market competition. Thus, this paper seeks to investigate whether the standard framework of target costing in the literature applies - with or without adjustments to real estate developers. Case study was the research strategy adopted. Guidelines are proposed for the introduction of target costing in the development process of residential real estate products. The proposed guidelines are related to the three main sections of the target costing process: market-driven costing, product-level target costing and component-level target costing.
\end{abstract}

Keywords: Target costing. Real estate. Product development process.

\section{Resumo}

Este estudo concentra-se nos problemas associados à prática tradicional de redução de custos na construção civil e na necessidade de aumentar a competitividade das empresas do setor imobiliário residencial. Nesse contexto, o custeio-meta é uma abordagem promissora para melhorar a competitividade das empresas, assegurando que os produtos lançados no mercado não comprometam os resultados da empresa e a entrega de valor aos clientes. No entanto, muito pouca atenção tem sido dada à implementação do custeio-meta pelas empresas

Reymard Savio Sampaio de Melo Universidade Federal do Rio Grande

do Norte Natal - RN - Brasil

Ariovaldo Denis Granja Universidade Estadual de Campinas Campinas - SP - Brasil

Recebido em 28/11/16 Aceito em 21/03/17 que desenvolvem produtos habitacionais para venda e enfrentam forte

concorrência no mercado. Assim, este artigo procura investigar se o arcabouço conceitual do custeio-meta se aplica - com ou sem ajustes - aos incorporadores imobiliários. $O$ estudo de caso foi a estratégia de pesquisa adotada. Diretrizes são propostas para a introdução de custeio-meta no processo de desenvolvimento de produtos imobiliários residenciais. As diretrizes propostas estão relacionadas às três seções principais do processo do custeio-meta: custeio orientado ao mercado, custeio-meta ao nível de produto e custeio-meta ao nível de componente.

Palavras-chave: Custeio-meta. Mercado imobiliário. Processo de desenvolvimento de produto. 


\section{Introduction}

Real estate companies usually face intense competition and, in order to be competitive, privately-held real estate companies must seek market niches, or overcome large open-end companies in speed of operation, product quality, processes, and decision and management systems (LIMA JUNIOR; MONETTI; ALENCAR, 2011). A privately held company is a company owned neither by non-governmental organizations nor by a relatively small number of shareholders or company members, which does not offer or trade its company stock (shares) to the public on the stock market exchanges, rather, the company's stock is offered, owned and traded or exchanged privately.

As competition in the real estate sector becomes increasingly intense, a lower cost structure is critical for a company's survival. In this context, time-to-market reduction is a competitive advantage commonly pursued by residential real estate companies. Time-to-market is the strategy of focusing on reducing the time to introduce new products in the market (PAWAR; MENON; RIEDEL, 1994). Time plays a role in the two following ways of generating profit: (i) reducing delays can reduce the cost through the reduction of financial immobilization, (ii) and, based on an economic analysis of first mover advantage, creating value in markets where obsolescence is central (MAHMOUD-JOUINI; MIDLER; GAREL, 2004).

Real estate developers do not have the time to design residential units, realize that they cost too much and then redesign them. Such practice extends the product development cycle and delays product launch. In the context of a competitive environment and the time-to-market strategy, the discipline that target costing (TC) brings to the product development process can help increase the likelihood that the costs of new products are acceptable when they are launched. Hence, TC is intimately related to an organization's competitive strategy and its product development cycle (ANSARI; BELL; CAM-I..., 1997).

Whereas in the manufacturing industry TC has a market-driven product development process and its intellectual roots lie in the "open system" theory (ANSARI; BELL; CAM-I..., 1997), most earlier studies on TC in construction (NICOLINI et al., 2000; BALLARD; REISER, 2004; ROBERT; GRANJA, 2006) focused on companies procuring means of production for their own use. Real estate developers differ from these companies. In fact, Real estate developers are in a very similar position to manufacturing companies developing new products. Research is needed to investigate whether the standard descriptions of TC in the Architecture, Engineering, and Construction (AEC) literature apply - with or without adjustment - to real estate developers.

According to the systems theory concept, traditional cost plus ("closed systems" approach) and TC ("open systems" approach) differ in four aspects: the relationship with the external environment, the number of variables considered, the form of regulation, and the purpose of regulation or control. A "closed system" approach ignores the interaction between an organization and its environment by focusing on internal measures of efficiency, it does not consider the cross-functional or extraorganizational impact of the cost system, takes corrective action after observing actual results, and keeps costs to a prespecified limit set by standards or budgets. On the other hand, an "open system" approach interacts with the external environment to respond to customer needs and competitive threats, it considers many complex relationships among functions and across the value chain, takes corrective action before actual outcomes occur and focuses on the continuous improvement of costs for both customers and producers over a product's life cycle (ANSARI; BELL; CAM-I..., 1997). Thus, we claim that the "open system" approach represented by TC can closely resemble the dynamics of the real estate market, once companies in this situation develop products for sale and face strong market competition.

Previous studies have shown that TC implementation in the Brazilian real estate market remains poorly explored with regard to readiness assessment by companies seeking to adopt such strategic innovation. Hence, this study questions the assumption that the TC framework works as is for real estate developers. This paper seeks to examine whether the standard TC framework in the literature applies with or without adjustments to real estate developers.

This article is structured as follows: Section titled 'What is target costing?' presents a literature review on TC and target value design (TVD), the following section is devoted to the research method adopted in the study, Section titled 'Findings' shows an analysis and the results of this study, Section titled 'Proposed Guidelines' presents the proposed guidelines and their contribution to theory and practice. Finally, the last section presents the study's conclusions. 


\section{What is target costing?}

TC was originally introduced in Japan under the name of Genka Kikaku (NICOLINI et al., 2000) and became popular in the management accounting literature in the 1990s. TC is a broad concept and has been used with a variety of meanings in the literature. Ballard (2008) defined it as a conversation between allowable and expected cost. Cooper and Slagmulder (1997) defined TC as " [...] a structured approach to determine the life-cycle cost at which a proposed product with specified functionality and quality must be produced to generate the desired level of profitability over its life cycle when sold at its anticipated selling price [...]". In Japan, lean companies have learned to view TC not as a stand-alone program, but as an integral part of the product development process (COOPER; SLAGMULDER, 1999).

For the purpose of this article, the term TC is used in its broadest sense to refer to a "[ ...] market driven costing system in which cost targets are set by considering customer requirements and competitive offerings. Cost targets are achieved by focusing on product and process design and by making continuous improvements in all support processes [...]" (ANSARI; BELL; CAM-I..., 1997).

While TC procedures at companies can vary considerably, Cooper and Slagmulder (1997) proposed a general structure, which is divided into three major sections: market-driven costing, product-level target costing, and com ponent-level TC as shown in Figure 1.

\section{Implementing TC in organizations}

TC can be applied in a number of different ways within an organization. The range of TC applications varies from a stand-alone to a full integration application. First, in a stand-alone application, a single department within an organization can apply TC to offer goals for itself and its suppliers. Second, a TC application can support a specific program. In this approach, TC is used on an ad hoc basis to tackle a particular issue and it is not institutionalized within the organization (ELLRAM, 1999). Third, a TC application can be an externally driven process to meet specific market conditions, customer requirements, and competition. Fourth, a TC application can be institutionalized as a way of doing business within the organization. Finally, a TC application can also be used as an integral effort across the supply chain. At this stage, suppliers and key sub-suppliers are involved in the product development through early participation and value methodology (ELLRAM, 1999).

\section{TC within the project-based environment of construction}

Over the past decades, TC implementation in the construction industry has been studied in different project environments. One of the first studies that documented TC in the construction industry was published by Knott (1996), who described British Petroleum's effort to implement target costing in the development of the Andrew Oil Field. Nicolini et al. (2000) investigated the application of TC through an action research in two UK projects. Their study suggested that general contractors in the UK construction sector had lost the ability to manage cost, and attended only to prices. Thus, TC application is seriously jeopardized in this context.

Ballard and Reiser (2004) reported the first application of TC in the United States construction industry on the St. Olaf Fieldhouse Project. Yook, Kim and Yoshikawa (2005) conducted a survey to determine the status of TC application in the Japanese construction industry. The results of their study showed that TC was being developed by each company independently from others.

Figure 1 - The three main elements of the TC process

\begin{tabular}{|c|c|c|c|}
\hline \multirow[b]{2}{*}{$\begin{array}{c}\text { Market-driven } \\
\text { costing }\end{array}$} & $\begin{array}{l}\text { Consumer } \\
\text { demands }\end{array}$ & \multicolumn{2}{|c|}{$\begin{array}{l}\text { Cost-reduction } \\
\text { pressure }\end{array}$} \\
\hline & & $\begin{array}{l}\text { Product-level } \\
\text { target costing }\end{array}$ & $\begin{array}{l}\text { Component-level } \\
\text { target costing }\end{array}$ \\
\hline & $\begin{array}{c}\text { Product } \\
\text { specification } \\
\text { changes }\end{array}$ & & \\
\hline
\end{tabular}

Source: adapted from Cooper and Slagmulder (1999). 
Kern, Soares and Formoso (2006) focused on TC applicability in the development of a Brazilian industrial project. Guadanhim, Hirota and Leal (2011) proposed a set of guidelines to enable TC application in the design process of Brazilian lowincome housing projects. The Brazilian social housing context was also studied by Jacomit and Granja (2011), who proposed a framework intended to demonstrate how the TC system could be applied in association with the product development process of Brazilian public social housing projects. Besides proposing the framework, they compared the TC literature with the current product development process of social housing projects in order to identify contextual characteristics that would:
(a) increase TC applicability;
(b) reduce TC applicability; or
(c) drive its implementation process.

These studies have shown that research on TC application in the real estate sector are particularly scarce, yet urgently needed in order to investigate whether TC theory needs refinement.

\section{Target Value Design and the real estate market}

TVD is an adaptation of the original target costing concept to the peculiarities of the construction industry (ZIMINA; BALLARD; PASQUIRE, 2012). The term "Target Value Design" was first coined by Macomber, Howell and Barberio (2007). More recently, the term "Target Value Delivery" has emerged to emphasize that TVD is applicable beyond the design phase (DO; BALLARD; TILLMANN, 2017). The 17 elements of the TVD process benchmark proposed by Ballard (2011) represent the main intellectual foundations of TVD. TVD relies on a systemic approach, which includes TC principles with an alternative project organization (value-based selection as opposed to lowest bid procurement routes), the use of relational contracts (such as Integrated Project Delivery) and a lean system of operation (ZIMINA; BALLARD; PASQUIRE, 2012).

While TVD has mostly been implemented in the U.S. construction industry, particularly in healthcare (MELO et al., 2015, ALVES; LICHTIG;
RYBKOWSKI, 2017) and in energy efficiency retrofit projects (LEE, 2012), the appropriateness of the current TVD benchmark to be adopted in the real estate market, such as residential developments with units for sale, is still poorly explored. The distinctiveness of this context has encouraged recent studies about the opportunities for strengthening TVD's current process benchmark, by first revisiting the roots of the TC framework (OLIVA et al., 2016; MORÊDA NETO; COSTA; THOMAS, 2016). Indeed,

The mindset of real estate property developers tends mainly to relate TVD benefits to a potential approach to develop competitive advantage in a rather aggressive environment such as the real estate market. For this reason, revisiting the original theory of TC product development could bring additional insights for possible adaptions for TVD better suitability to this context [...] (OLIVA et al., 2016).

The original TC theory was conceived within a context that could be said to partly resemble the dynamics of the real estate market. The similarity lies in the fact that in this situation, companies develop products for sale and face strong market competition. This is in harmony with the marketoriented perspective of TC (COOPER; SLAGMULDER, 1997) and with the adherence of TC to the "open systems" approach (ANSARI; BELL; CAM-I..., 1997). Therefore, the suitability of TVD for adoption in real estate seems to be dependent upon the strengthening of its marketdriven orientation, in terms of necessary external interactions to identify the customers' needs and competitive forces (Table 1).

\section{Research method}

The research strategy is framed as an exploratory case study (YIN, 2009). Exploratory case studies are suited for giving insights and refining a body of theory. By understanding a specific case, the questions about how to adopt TC's original concepts in such a unique situation as the real estate market might be answered. We adopted a deductive approach and started with the original framework of TC costing, as used in manufacture. This provided guidance on relevant data, which should be collected from the case study. 
Table 1 - TVD suitability for the real estate market

\begin{tabular}{|l|l|l|}
\hline \multicolumn{1}{|c|}{$\begin{array}{c}\text { Systems Theory } \\
\text { Concept }\end{array}$} & \multicolumn{1}{|c|}{ Target Costing (open systems) } & \multicolumn{1}{c|}{ Target Value Design } \\
\hline $\begin{array}{l}\text { Relations with } \\
\text { external } \\
\text { environment }\end{array}$ & $\begin{array}{l}\text { Interacts with external environment to } \\
\text { respond to customer needs and competitive } \\
\text { threats. }\end{array}$ & $\begin{array}{l}\text { Opportunity to strengthen the } \\
\text { current TVD process benchmark }\end{array}$ \\
\hline $\begin{array}{l}\text { Number of } \\
\text { variables } \\
\text { considered }\end{array}$ & $\begin{array}{l}\text { Considers many complex relationships } \\
\text { among functions and across the value } \\
\text { chain. }\end{array}$ & $\begin{array}{l}\text { Concept covered in the current } \\
\text { TVD process benchmark }\end{array}$ \\
\hline Form of regulation & $\begin{array}{l}\text { Before the fact, by anticipating and } \\
\text { designing the costs out of a product before } \\
\text { production. }\end{array}$ & $\begin{array}{l}\text { Concept covered in the current } \\
\text { TVD process benchmark }\end{array}$ \\
\hline $\begin{array}{l}\text { Purpose of } \\
\text { regulation }\end{array}$ & $\begin{array}{l}\text { Continuous improvement of cost for both } \\
\text { customers and producers over a product's } \\
\text { life. }\end{array}$ & $\begin{array}{l}\text { Concept covered in the current } \\
\text { TVD process benchmark }\end{array}$ \\
\hline
\end{tabular}

Source: adapted from Ansari and Bell and CAM-I Target Costing Group (1997).

The selected real estate developer ranked $7^{\text {th }}$ in the 2014 ITC (Portuguese acronym for Construction Business Intelligence) Ranking of the 100 largest contractors in Brazil. The researcher did not use formal procedures for data collection during the early meetings with the members of the organization. The first meeting was intended to give the members of the company an overview of the TC approach, how it works, and who uses it. Once the national manager decided to support the case study, he nominated a sponsor. The sponsor's role was to provide all the necessary support to the researcher during the study. The case study was divided into three phases: Understanding, Introduction of TC principles and Assessment.

The aim of the Understanding Phase was to grasp the company's product development process. The sources of evidence used in this phase were meetings with members from the company's Engineering, Development \& Projects, Budget and Supplies departments, as well as direct observation of a design charrette.

As a fully-fledged TC implementation requires radical changes in terms of design process and coalitions between the developer and other stakeholders, the purpose of the Introduction of TC principles phase was to introduce two of the six key TC principles described by Ansari, Bell and CAMI Target Costing Group (1997) in the design process of a pilot project of the company. The two TC principles tested were "Focus on customer" (to guide cost analysis) and "Focus on design". In line with this objective, the introduction was divided into two steps:

(a) identification of the potential apartment buyers' desired value by using the stated preference technique (BRANDLI; HEINECK, 2005); and (b) conduct of a value methodology exercise by participant observation of the researcher.

The stated preference technique presents several alternatives to the respondents, and only one is chosen. The selected alternative indicates the respondents' preferred choice of attributes in relation to other alternatives (BRANDLI; HEINECK, 2005). The stated preference technique with 26 illustrated cards to collect end-users desired values was used according to previous research (KOWALTOWSKI; GRANJA, 2011). The 26 cards represent design values to be investigated among end-users of residential units. A detailed discussion of the value assessment method can be found in Kowaltowski and Granja (2011), as it is not fully presented in this article because of space limitations.

Due to the exploratory nature of this study, it was not possible to apply the stated preference technique with potential buyers of the residential units. The technique was applied with a convenience sample of 13 of the company's employees: seven members (architects) from the product development department, two members from the budget department, one member from the quality department, one member from the licensing department and two members from the third-party management department. Hence, any sound statistical inference is beyond the scope of the study.

Once the desired value attributes were identified, the researcher proposed conducting a value methodology exercise through simple cost reallocation (RUIZ; GRANJA; KOWALTOWSKI, 2014), where the participants were asked to document, assess and approve design changes/innovations. For the sake of simplicity, it was only possible to document design 
modifications/innovation proposals. Each design change/innovation was documented on an evaluation sheet. Subsequently, the budget department assessed the cost reduction impact of each proposal and submitted them to the approval process.

Finally, the aim of the Assessment Phase was to describe the main barriers faced in the introduction of the basic principles of TC. The findings of the case study were later presented to one of the company's top managers, who decided to continue the effort to introduce TC principles in the company. This real estate developer is now seeking to enhance its competitive offerings in the real estate market by setting cost targets and considering the input of customers' values in the product development process. This is a remarkable improvement in mindset, since the company used to "push value propositions" primarily on the basis of "sellable product attributes".

\section{Findings}

\section{Understanding phase}

The real estate developer has a set of 15 products classified into three categories: Family (entry, transition and established), Commercial (offices, retail and companies' headquarters) and Niche (second homes and exclusive properties). The company's current product development process is a sequential, linear and highly fragmented process from land acquisition to launch. The product development process consists of two cycles: Land acquisition and real estate development. The cycle of land acquisition lasts from 4 to 6 months. The cycle of real estate development (from design to launch) lasts from 12 to 18 months.

During the Design Development phase, a design charrete is often held. A design charrete is a collaborative meeting in which members of the product development process (architect, mechanical, electrical and plumbing engineers, structural engineer, landscape architect and interior designer) collaborate and sketch designs to explore and share ideas over a predetermined period.

Since the developer often uses a standard design for each residential project, design changes are usually necessary to suit site conditions and local regulations. Moreover, this meeting also serves to detect potential clashes in the design stage before the start of the construction process.

\section{Introduction of Target Costing principles phase}

The pilot project consisted of two 16-storey connected towers with nine apartments per floor. The respondents were asked to answer from the perspective of potential buyers. In the first cycle, the respondents were asked to rank their preferences of value attributes in five different categories (KOWALTOWSKI; GRANJA, 2011):
(a) financial aspects;
(b) spatial qualities;
(c) indoor environmental quality;
(d) socio-cultural perceptions; and
(e) cultural values.

The socio-cultural perceptions category covers six value attributes, while the remaining four consist of five attributes.

In the second cycle, the respondents were asked to rank the five priority choices in each of the categories chosen in the previous cycle. Value attributes are organized in Table 2 according to the number of times they were cited by respondents. The 26 illustrated cards intentionally underpin broad value perceptions, therefore making the application of the exercise very straightforward. In order to properly transfer the desired values to design solutions, designers need to rely on creativity and on lessons learned from previous similar products, as well as facilitate innovation to assist the design process.

Although the participants had no previous experience/training in value methodology techniques, the underlying idea was to reduce project cost, and achieve value enhancement through simple cost reallocation. Table 3 shows the participants of the value methodology exercise.

The researcher made a brief presentation to the participants about the TC approach. The researcher also acted as a facilitator at the meeting and presented the following information:
(a) project cost estimate ( $\sim$ U $12,000,000)$;
(b) drawings, including floor plans, sections, elevations, roof plan, parking plan; and

(c) desired value attributes as shown in Table 2.

The brainstorming session resulted in twenty-two proposals for design changes, which would potentially reduce the project cost without compromising the value delivered to end-users. The proposals were minor design changes and represented a $1 \%$ reduction in the overall project cost. However, some of the changes were not 
approved by the company's development and engineering departments. For instance, the design team proposed removing the barbecue grill from the apartment balcony. The project would be built in the southern region of Brazil, where barbecue cooking is a very prominent aspect of the local culture, therefore, the removal of this element would affect apartment sales. The replacement of the brick swimming pool in the building's common area by a fiberglass swimming pool was another design change not approved by the company's development department.

Table 2 - Desired value attributes ( 21 cards rated from a total amount of 26)

\begin{tabular}{|c|c|c|}
\hline Card & Value Attributes & $\begin{array}{l}\text { \# of citations } \\
\text { by respondent }\end{array}$ \\
\hline Fु & Rent instalments & 8 \\
\hline & Sense of place & 8 \\
\hline एलिखी & Acoustics & 5 \\
\hline 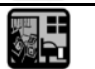 & Different apartment layout & 5 \\
\hline & Size of rooms & 5 \\
\hline & Green spaces & 4 \\
\hline & Smaller housing schemes (reduced number of buildings per housing project) & 4 \\
\hline & Security & 3 \\
\hline & Finishing quality & 3 \\
\hline & Thermal comfort & 2 \\
\hline 60 & Natural lighting & 2 \\
\hline & Varied appearance of buildings & 2 \\
\hline & New spaces & 2 \\
\hline s & Business opportunities & 1 \\
\hline Aी & Parking areas & 1 \\
\hline 8 & Ornamentation (decorative elements) & 1 \\
\hline (is & Larger apartments & 1 \\
\hline 成 & Size and location of windows and doors & 1 \\
\hline 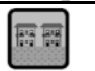 & Buildings with a residential appearance & 1 \\
\hline 消: & Transportation costs & 1 \\
\hline 象象 & Running costs (utility bills) & 1 \\
\hline
\end{tabular}

Source: adapted from Kowaltowski and Granja (2011). 
Table 3 - Participants of the value methodology exercise

\begin{tabular}{l|c}
\hline Company's department/stakeholders & \# of participants \\
\hline Budget Department & 2 \\
Development \& Projects Department & 3 \\
Engineering Department & 1 \\
Quality Department & 1 \\
Structural engineer & 1 \\
Architecture & 2 \\
MEP engineers & 2 \\
Prefabricated exterior wall supplier & 1 \\
Drywall supplier & 2 \\
\hline
\end{tabular}

\section{Assessment phase}

The lessons learned from the case study are briefly described in this section. By the time the value methodology exercise began, the design process was already in the Construction Documents phase. Therefore, the proposed design changes had none or low-impact in the overall cost of the project.

All cost reduction efforts would be guided by the "voice of the customer" (represented here by the desired value attribute list), however, some participants underestimated its importance. For instance, one of the design changes proposed during the value methodology exercise was to remove the internal wool of the drywall partitions. Five of the 13 respondents cited the apartment's acoustics as a potential end-user's desired value attribute. The proposed design change would reduce the project cost, but it would potentially undermine the value delivered to the end-user.

The value methodology exercise results were later presented to the national manager of the company. The national manager recognized that the value methodology exercise would have more impact on the project cost if it were applied in the early stages of the product development process. He also stated that future TC implementation efforts would require a sponsor with a strong strategic background rather than a merely technical one.

The recognition of these limitations and the potential of the TC approach led to the decision to run a second pilot study during the early stages of a project's development. The national manager also suggested future actions that would be needed to address the limitations identified in the study. The first action would be to identify the desired values of end-users of similar projects developed by the company rather than to identify the desired values of end-users from the perspective of the company's employees. A second future action would be to identify specific design attributes directly related to the most desired values by end-users.

\section{Proposed guidelines}

Table 4 summarizes the proposed guidelines for TC adoption in real estate, which are rooted in previous TC literature (ANSARI; BELL; SWENSON, 2006; COOPER; SLAGMULDER, 1999; JACOMIT; GRANJA, 2011; RUIZ; GRANJA; KOWALTOWSKI, 2014) and also supported by the lessons learned from the case study.

\section{Pre-Target Costing guidelines}

Define a TC implementation purpose: It is essential to make clear the company's expectations as well to identity the main rationale behind the implementation process. For instance, if the implementation purpose is to increase the company's competitiveness, then the implementation process likely has a market orientation. An analysis of the internal factors (i.e. strengths and weaknesses) and external factors (i.e. opportunities and threats) that affect the organization would shape an implementation strategy.

Do a readiness assessment: One approach might be to use a simulation game. Besides applying basic TC principles in a risk-free environment, such simulation would allow the organization to get acceptance from the design team.

Develop a multi-year implementation plan: TC implementation often requires radical changes in the entire product development process. The development of a multi-year implementation plan corroborates the idea proposed by Ansari, Bell and Swenson (2006) that an organization is unlikely to complete and institutionalize TC in just one year. This implementation plan could also be aligned with the company's strategic plan. In addition, it could include a review of existing policies and values. 
Table 4 - Proposed guidelines for TC adoption in real estate

\begin{tabular}{|c|}
\hline PRE-TARGET COSTING GUIDELINES \\
\hline Define a TC implementation purpose \\
\hline Do a readiness assessment \\
\hline Develop a multi-year implementation plan \\
\hline Identify an appropriate pilot project \\
\hline MARKET DRIVEN GUIDELINES \\
\hline Structure the product line based on how customer preferences change over time \\
\hline Set target-selling price \\
\hline Set preliminary profit margin \\
\hline Compute allowable cost \\
\hline PRODUCT-LEVEL GUIDELINES \\
\hline Analyze the ability of the company's designers and suppliers to reduce costs from the proposed product \\
\hline Set a product development approach and a design strategy \\
\hline Break down the target cost into major functions or building systems \\
\hline Identify cost reallocation opportunities considering the value proposition of potential buyers \\
\hline COMPONENT-LEVEL GUIDELINES \\
\hline Set target costs for components \\
\hline Select key suppliers and involve them so as to achieve targets and pursue innovation \\
\hline Identify cost reduction opportunities by means of value methodology \\
\hline
\end{tabular}

Identify an appropriate pilot project: This case study revealed that the value methodology exercise would have more impact on the project cost if carried out in the early stages of the product development process. TC should be applied to either a new product in the concept phase or a product that needs major redesign (ANSARI; BELL; SWENSON, 2006). As suggested by Cooper; Slagmulder (1997), a pilot project should:

(a) reveal the magnitude of possible cost savings by using the TC approach;

(b) have a limited scope to be completed in a reasonable length of time; and

(c) be large enough to create visibility in the company to justify a fully-fledged implementation.

\section{Market driven costing guidelines}

Structure the product line based on how customer preferences change over time: Through the identification of costumer mindsets, a company can use them to identify specific design attributes or market trends that customers keep in mind while purchasing a new property (e.g., gourmet balcony and individual apartment water metering were potential desirable attributes mentioned, as stated by one of the design team members). There are several techniques to identify buyers' preferences (e.g. the 26 cards used in the case study). Once a company discovers clusters of these preferences, it can identify niches to introduce a real estate product tailored precisely for its potential buyers.
Set target-selling price: The understanding of customers' perceived value for a product is the starting point in the price-setting process. Customers will pay more for a product than they did for its predecessor only if they perceive an increase in the value they will receive. Developing market intelligence about average selling prices of similar products could be a potential approach to set a product's target-selling price.

Set target profit margin: The approved selling price, the overall sales volume and the company's longterm strategy will define the target profit margin. The company selected for this research study had set the same profit margin for every product in its product family, regardless of external market conditions. However, Cooper and Slagmulder (1999) suggest that companies should instead raise or lower the target profit margin for individual products, according to the realities of the marketplace. More research is necessary, since this issue is seen as very sensitive by real estate companies.

Compute allowable cost: As a pivotal rule of the TC approach, the allowable cost is calculated by subtracting the target profit margin from the target selling price.

\section{Product level guidelines}

Analyze the ability of the company's designers and suppliers to reduce costs from the proposed product: The allowable cost does not reflect the current capabilities of the company and its suppliers, which means that it is a simple 
calculation. It reflects only the market's demands and the company's profit requirements. Therefore, the company should incorporate those realistic capabilities when setting an achievable target cost.

Set a product development approach and a design strategy: A lean product development process (nondepartmentalized or non-fragmented) is best suited to the TC approach. The design charrete described in the case study can be a promising approach to integrate the product development process. A company could also pursue a set-based design strategy, allowing the selection among design alternatives to be made at the last responsible moment. According to the evidence collected, the company studied adopts instead a full point-based approach to develop its products.

Break down the target cost into major functions or building systems: A company can perform a function analysis (KOGA, 2010) of a given project or simply break down the target cost of a project into the main building systems and subsystems.

Identify cost reallocation opportunities considering the value proposition of potential buyers: Several techniques can help designers to achieve the target cost of the major functions, such as:

(a) tools and techniques rooted on a value methodology approach;

(b) design for manufacturability and assembly, and design to cost;

(c) cost tables (YOOK; KIM; YOSHIKAWA, 2005);

(d) feature to function costing;

(e) component cost analysis;

(f) process costing;

(g) multiyear product and profit planning; and

(h) benchmarking (ANSARI; BELL; CAM-I..., 1997).

\section{Component-level guidelines}

Set the target costs of components: The process of setting component-level target costs is similar to setting the target cost of major functions or building systems. However, the target cost for components should be set when the design has reached the construction documents phase, i.e. when ready for production.

Selecting key suppliers and involving them to achieve targets and pursue innovation: A company can identify key suppliers through ABC Analysis (similar to the Pareto principle in that the 'A' suppliers will typically account for a large proportion of the overall value but a small percentage of the number of items). In addition, the adoption of industrialized production systems in construction, "modularity" for instance (VOORDIJK; MEIJBOOM; DE HAAN, 2016), could induce the adoption of a strong supplierdriven strategy and the use of standard components and interfaces (ULRICH, 1995). In construction supply chains, these somewhat new forms of organization could increase collaboration between owner, designers and module suppliers. In this sense, value would be transferred from the contractor to other stakeholders, mainly the supplier (DORAN; GIANNAKIS, 2011).

Identify cost reduction opportunities by means of value methodology: The same techniques used to achieve the cost of the major functions could be employed. Furthermore, the target cost of components could be achieved by a cost reallocation exercise driven by the end-users' desired values (RUIZ; GRANJA; KOWALTOWSKI, 2014).

\section{Contribution to refining the TC theory for adoption in the real estate market}

The proposed guidelines are in line with previous research (ANSARI; BELL; SWENSON, 2006; COOPER; SLAGMULDER, 1999; JACOMIT; GRANJA, 2011; RUIZ; GRANJA; KOWALTOWSKI, 2014). However, few studies in the construction field have addressed aspects related to the phase prior TC implementation. The contribution brought by the pre-target costing guidelines is to shed light on activities that should be performed before a formal TC implementation attempt. As previously mentioned, the range of TC adoption varies from a stand-alone to a fully integrated application. Therefore, defining the purpose of a TC implementation is critical to guide future actions and shape the implementation strategy.

The market-driven guidelines of TC are directly related with market intelligence, which consists in the information about a company's potential customers and competitors that is used for business decision-making purposes. Market intelligence and strategic information systems are indispensable for the success of TC (NICOLINI et al., 2000). These guidelines can be particularly relevant to companies that operate in competitive markets such as real estate.

The real estate market has its own dynamics and peculiarities. For instance, land cost is a major item in any typical real estate development. Real estate developers are often concerned with which product 
can be sold to cover land and building costs and also the required profit margin. Furthermore, real estate developers might be faced with the realities of confrontational strategies, which are commonly adopted by lean-oriented companies. This is an environment where many companies compete for the same customers by developing equivalent products (COOPER; SLAGMULDER, 1997).

In a lean mindset environment, companies confront each other in order to challenge their current competence benchmark, so that their survival in an extremely competitive market is secured. Therefore, understanding customers' perceived value is also critical for the entire product development process in real estate, including the price setting process and the cost reduction- and reallocation process. This understanding is also important for translating customers' perceived values into design attributes.

The product-level guidelines also rely on the existing TC literature except for the third proposed guideline, namely, "Set a product development approach and a design strategy". The contribution of this guideline lies in the fact that the chosen product development approach plays a critical role in the TC implementation process. The departmentalized or batch-and-queue product development identified in this case is not favorable to TC implementation due to its lack of integration. It often includes redesign activities and queues between departments.

The component-level guidelines are related to the level of supply management involvement in the TC process. This involvement can range from very limited to being the driver of the entire process. As suggested by Ellram (1999), the supply management roles during the component-level TC are: to provide historical data, to provide supplier cost estimates and to begin supplier negotiations. In the construction industry, suppliers are often selected based on the competitiveness of their bid and get involved too late in the design process.

\section{Contribution to practice}

The proposed guidelines are structured into the TC process steps. Before following the proposed guidelines, an organization should assess its readiness for change and be aware that large-scale implementation takes time.

In addition, a crucial step for the successful implementation of the proposed guidelines is to set up a central implementation team. The central implementation team keeps the implementation process moving forward through planning, training and support.

Since most construction companies in Brazil have very little experience in the TC process, training programs could focus on building awareness and acceptance among the design team as well as on increasing technical capabilities in value methodology techniques.

As part of the implementation plan, the organization could also review existing internal policies and procedures that manage the governance between contractor, subcontractors and suppliers. The ability to extend the implementation process beyond the company's boundaries relies on the level of cooperation and trust between the company and its suppliers.

TC is most effective when applied in the context of long-term supplier relations that are cooperative in nature. It is widely known that the nature of supplier relations in the construction industry is often associated with adversarial relations and mistrust. Replacing the traditional cost reduction activity of "squeezing" the subcontractors by collaborating with key subcontractors/suppliers on cost reduction ideas and on a fair distribution of risk among stakeholders is also a major hurdle to overcome.

A shared understanding of TC by a specific organization and its individuals can be achieved by interacting with the proposed guidelines. The guidelines can stimulate discussions about TC within an organization, which are necessary to build awareness and motivate actions to either start or continue a TC journey.

\section{Conclusion}

TC implementation in the construction industry has been studied in several countries and projects. To date, far too little attention has been paid to TC implementation by companies that develop products for sale and face a strong competition in the real estate market. This paper contributes to the existing body of knowledge by introducing guidelines for TC introduction in the product development process of real estate companies seeking to sell residential units. A secondary outcome of this study was the use of the research opportunity to raise questions about how to strengthen TVD's current benchmark for the real estate context.

One limitation of this study stems from the fact that the proposed guidelines were not validated in practice nor have they been adopted by any real estate companies as yet. Thus, in order to expand the applicability of the proposed guidelines, in the future, researchers can conduct an exploratory focus 
group to refine the proposed guidelines. Another possible area of future research would be to conduct confirmatory focus groups to establish the utility of the proposed guidelines. It would be interesting to implement and refine these guidelines in multiple circumstances.

\section{References}

ALVES, T.C.L; LICHTIG, W; RYBKOWSKI, Z. Implementing Target Value Design. HERD: Health Environments Research \& Design Journal, p. 1-12, 2017.

ANSARI, S.; BELL, J.; CAM-I TARGET COSTING GROUP. Target Costing: the next frontier in strategic cost management. Chicago: Irwin, 1997.

ANSARI, S.; BELL, J.; SWENSON, D. A Template for Implementing Target Costing. Cost Management; v. 20, n. 5, p. 20-27, 2006.

BALLARD, G.; REISER, P. The St. Olaf College Fieldhouse Project: a case study in designing to target cost. In: BERTELSEN, S.; FORMOSO, C. T. ANNUAL CONFERENCE OF THE INTERNATIONAL GROUP FOR LEAN CONSTRUCTION, 12., Hlesingor, 2004. Anais... Helsingør, 2004.

BALLARD, G. The Lean Project Delivery System: An Update. Lean Construction Journal, v. 4, n. 1, p. 1-19, 2008.

BALLARD, G. Target Value Design: Current Benchmark (1.0). Lean Construction Journal, v, 6, n. 1, p. 79-84, 2011.

BRANDLI, L.; HEINECK, L. As Abordagens dos Modelos de Preferência Declarada e Revelada no Processo de Escolha Habitacional. Ambiente construído, Porto Alegre, v. 5, n. 2, p. 61-75, abr./jun. 2005.

COOPER, R.; SLAGMULDER, R. Target Costing and Value Engineering. New York: Productivity Press, 1997.

COOPER, R.; SLAGMULDER, R. Develop Profitable New Products with Target Costing, Sloan Management Review, v. 40, n. 4, p. 23-33, 1999.

DO, D.; BALLARD, G.; TILLMANN P. Application of Target Value Design in the Design and Construction of the UHS Temecula Valley Hospital: part 1 of 5. Disponível em: <http://p2sl.berkeley.edu/wpcontent/uploads/2016/03/Do_Ballard_Tillmann2015-Application-of-TVD...-UHS-TemeculaValley-Hospital.pdf>. Acesso em: 15 mar. 2017.
DORAN, D.; GIANNAKIS, M. An Examination of a Modular Supply Chain: a construction sector perspective. Supply Chain Management: an International Journal, v. 16, n. 4, p. 231-245, 2011.

ELLRAM, L. M. The Role of Supply Management in Target Costing. Tempe: Center for Advanced Purchasing Studies, 1999.

GUADANHIM, S. J.; HIROTA, E. H.; LEAL, J. G. Análise da Aplicabilidade do Custeio-Meta na Etapa de Concepção de Empreendimentos Habitacionais de Interesse Social. Ambiente Construído, Porto Alegre, v. 11, n. 2, p. 39-56, abr./jun. 2011.

JACOMIT, A. M.; GRANJA, A. D. An Investigation Into the Adoption of Target Costing on Brazilian Public Social Housing Projects.

Architectural Engineering and Design Management, v. 7, n. 2, p. 113-127, 2011.

KERN, A. P.; SOARES, A. C.; FORMOSO, C. T. Introducing Target Costing in Cost Planning and Control: a case study in a Brazilian Construction Firm. In: CIB W107 CONSTRUCTION IN DEVELOPING COUNTRIES INTERNATIONAL SYMPOSIUM "CONSTRUCTION IN DEVELOPING ECONOMIES: NEW ISSUES AND CHALLENGES", Santiago, 2006. Anais... Santiago, 2006.

KNOTT, T. No Business as Usual, BP Education, London, 1996.

KOGA, J. E. Function Analysis in Integrated Project Development. In: ANNUAL CONFERENCE OF SAVE INTERNATIONAL, 50., Long Beach, 2010. Proceedings... Long Beach, 2010.

KOWALTOWSKI, D.; GRANJA, A. The Concept of Desired Value as a Stimulus for Change in Social Housing in Brazil. Habitat International, v. 35, n. 3, p. 435-446, 2011.

LEE, H. W. Application of Target Value Design to Energy Efficiency Investments. PhD Thesis, University of California, Berkeley, 2012.

LIMA JUNIOR, J. da R.; MONETTI, E.; ALENCAR, C. T. Real Estate: fundamentos para análise de investimentos. São Paulo: Elsevier, 2010.

MACOMBER, H.; HOWELL, G.; BARBERIO, J. Target-Value Design: nine foundational practices for delivering surprising client value. The American Institute of Architects, Practice Management Digest, 2007. 
MAHMOUD-JOUINI, S.B; MIDLER, C.;

GAREL, G. Time-to-mArket vs. Time-to-Delivery Managing Speed in Engineering, Procurement and Construction projects. International Journal of Project Management, v. 22, n. 5, p. 359-367, 2004.

MELO, R. S. S. et al. Target Value Design in the Public Sector: evidence from a hospital project in San Francisco, CA. Architectural Engineering and Design Management, v. 12, p. 125-137, 2015.

MORÊDA NETO, H. M.; COSTA, D. B.; THOMAS, L. Target Value Design Approach for Real Estate Development. In: ANNUAL CONFERENCE OF THE INTERNATIONAL GROUP FOR LEAN CONSTRUCTION, 24., Boston, 2016. Anais... Boston, 2016.

NICOLINI, D. et al. Can Target Costing be Applied in the Construction Industry? Evidence from Two Case Studies. British Journal of Management, v. 11, n. 4, p. 303-324, 2000.

OLIVA, C. A. et al. Assessing Suitability of Target Value Design Adoption for Real Estate Developers in Brazil In: ANNUAL CONFERENCE OF THE INTERNATIONAL GROUP FOR LEAN CONSTRUCTION, 24., Boston, 2016. Anais... Boston, 2016.

PAWAR, K. S.; MENON, U.; RIEDEL, J. C. K. $\mathrm{H}$. Time to Market. Integrated Manufacturing Systems, v. 5, n. 1, p. 14-22, 1994.

ROBERT, G. T.; GRANJA, A. D. Target and Kaizen Costing Implementation in Construction. In: ANNUAL CONFERENCE OF THE INTERNATIONAL GROUP FOR LEAN CONSTRUCTION, 14., Santiago, 2006. Anais... Santiago, 2006.
RUIZ, J.; GRANJA, A.; KOWALTOWSKI, D. Cost Reallocation in Social Housing Projects Considering the Desired Values of End-Users. Built Environment Project and Asset Management, v. 4, n. 4, p. 352-367, 2014.

ULRICH, K. The Role of Product Architecture in the Manufacturing Firm. Research Policy, v. 24, n. 3, p. 419-440, 1995.

VOORDIJK, H.; MEIJBOOM, B.; DE HAAN, J. Modularity in Supply Chains: a multiple case study in the construction industry. International Journal of Operations \& Production Management, v. 26, n. 6, p. 600-618, 2006.

YOOK, K.; KIM, I.; YOSHIKAWA, T. Target Costing in the Construction Industry: evidence from Japan. Construction Accounting \& Taxation, v. 15, n. 3, p. 5-18, 2005.

YIN, R. K. Case Study Research: design and methods. Thousand Oaks: Sage, 2009.

ZIMINA, D.; BALLARD, G.; PASQUIRE, C. Target Value Design: using collaboration and a lean approach to reduce construction cost.

Construction Management and Economics, v. 30, n. 5, p. 383-398, 2012.

\section{Acknowledgements}

Thanks are due to the São Paulo Research Foundation for the concession of a scholarship to the first author. The authors would also like to thank the company that provided data for this study.

Reymard Savio Sampaio de Melo

Departamento de Engenharia Civil, Centro de Tecnologia | Universidade Federal do Rio Grande do Norte | Av. Senador Salgado Filho, 300 , Lagoa Nova | Natal - RN - Brasil | CEP 59078-970 | Tel.: (84) 3342-2518 | E-mail: smelo@ct.ufrn.br

\section{Ariovaldo Denis Granja}

Departamento de Arquitetura e Construção, Faculdade de Engenharia Civil, Arquitetura e Urbanismo | Universidade Estadual de Campinas | Av. Albert Einstein, 951, Cidade Universitária Zeferino Vaz, Barão Geraldo | Caixa Postal 6021 | Campinas - SP - Brasil | CEP $13083-852$ | Tel.: (19) 3521-2082 | E-mail: adgranja@fec.unicamp.br

\section{Revista Ambiente Construído}

Associação Nacional de Tecnologia do Ambiente Construído

Av. Osvaldo Aranha, $99-3^{\circ}$ andar, Centro

Porto Alegre - RS - Brasil

$$
\text { CEP } 90035-190
$$

Telefone: +55 (51) 3308-4084

Fax: +55 (51) 3308-4054

www.seer.ufrgs.br/ambienteconstruido

E-mail: ambienteconstruido@ufrgs.br 